Pak. j. sci. ind. res. Ser. B: biol. sci. 2019 62B(1) 8-14

\title{
Effect of Phosphorus Sources and their Levels on Spring Maize
}

\author{
Munir Ahmad ${ }^{\text {**, Ibrahim Khana, Dost Muhammad }}$, \\ Maria Mussarat ${ }^{\mathrm{b}}$ and Muhmmad Izhar Shafi ${ }^{\mathrm{a}}$ \\ aSchool of Environmental Science and Technology, Dalian University of Technology, Dalian 116024, China \\ ${ }^{b}$ Department of Soil and Environmental Sciences, The University of Agriculture Peshawar, Pakistan
}

(received January 18, 2016; revised November 15, 2017; accepted February 8, 2018)

\begin{abstract}
The present study was conducted in order to study the effect of $\mathrm{P}$ sources and their levels on spring maize crops at New Developmental Farm, University of Agriculture Peshawar, Pakistan in the year 2014. The farms were divided into low and high permeability strata. Clay loam to silt loam soil textures were observed in low permeability strata while sandy soils were observed in high permeability strata. Soil $\mathrm{pH}$ was dominantly alkaline in nature with no salinity indications. More than $75 \%$ samples were observed as moderate soil organic matter content. A basal dose of nitrogen $150 \mathrm{~kg} / \mathrm{ha}$ was applied at sowing time. Hybrid maize was sown with recommended population of $60000 \mathrm{plants} / \mathrm{ha}$. Four phosphorus (P) sources namely Diammonium phosphate (DAP), Nitrophosphate (NP), Triple superphosphate (TSP) and Single superphosphate (SSP), and four P levels (0, 60, 90 and $120 \mathrm{~kg} / \mathrm{ha}$ ) were applied at the time of sowing. Maximum plant height was observed by the application of NP at the rate $120 \mathrm{~kg} / \mathrm{ha}$. There was no significant effect of either P levels or P fertilizer sources on number of cobs per plant. Maximum grain per ear, thousand grain weight and highest harvest index was found by the application of SSP at the rate of $90 \mathrm{~kg} / \mathrm{ha}$. Higher biological and grain yield were produced when DAP was applied at the rate of $90 \mathrm{~kg} / \mathrm{ha}$. Regarding P levels, maximum electrical conductivity of $(0.20 \mathrm{dS} / \mathrm{m})$ was recorded for control. Maximum soil mineral nitrogen was recorded when NP was applied, while, highest plant P level was observed in case of SSP.
\end{abstract}

Keywords: phosphorus, spring maize, harvest index, biological yield, mineral nitrogen

\section{Introduction}

Maize (Zea mays L.) is the second most important crop after wheat in Khyber Pakhtunkhwa province of Pakistan, however, the yields per unit area are very low (Amanullah et al., 2009). It is a short duration crop and is used worldwide as food, feed and energy. Fats, protein, starch, minerals and vitamins represent the major nutritional constituents (Chen et al., 2016; Watson, 2003). Among all the crops, maize has the great nutritive value containing $72 \%$ starch, $10 \%$ protein, $8.5 \%$ fibre, $17 \%$ ash, $4.8 \%$ oil and 3\% sugar (Chaudhary, 1983). In Pakistan maize was grown on 1.01 million ha and the production was 3.08 million tonnes with an average yield of $3037 \mathrm{~kg} / \mathrm{ha}$, while in KPK it is grown on 0.5 million ha area and the production was 0.96 million tonnes with an average yield of $1780 \mathrm{~kg} / \mathrm{ha}$ in 2009 (GOP, 2011).

Maize growth and productivity greatly depends upon the genetic makeup of the variety, supply of essential nutrients required for plant growth as well as development in the area and plant density. The soil and climatic

*Author for correspondence;

E-mail: munirahmad089@gmail.com conditions of Pakistan are highly favorable for maize production. Pakistan also has high yielding maize varieties but the yield recovery of maize at farmer's fields are very low as compared to other maize producing countries including Canada, USA and Egypt etc. (Lee et al., 2016; Bakht et al., 2006).

Soils in Pakistan are mostly calcareous and alkaline in nature, which are generally deficient in phosphorus. Due to $\mathrm{P}$ deficiency, crop growth is restricted, as $\mathrm{P}$ is bound strongly with $\mathrm{Ca}, \mathrm{Mg}$ and other bases. Therefore, it is mostly unavailable for plants uptake (Rashid et al., 1999; Ahmad et al., 1992). Phosphorus has a key role on the physical properties of macromolecules like transfer of energy as ATP and nucleic acids in metabolic pathways for biosynthesis and degradation (Barber, 1995). Among different nutrients required for maize, phosphorus play a key role for improving maize yield by various physiological processes involved for growth (Zhu et al., 2005a; 2005b). High yielding varieties are more responsive to fertilizer application and their potential yield can be exploited by prudent use of phosphorus sources. Appropriate sources of $P$ fertilizer and proper application rate can increase the corn yield by $50 \%$ and stimulated seed formation (Zia et al., 1991). 
Amanullah et al. (2009) evaluated the effect of various sources of phosphorous on maize crops. Earlier physiological maturity of maize crops was recorded by application of SSP compared to DAP and NP fertilizers. Highest growth and grain yield was recorded with application of DAP. It was found that the effect of DAP was much better than other sources of phosphorous.

Phosphorus play an important role in root development, stem and stalk strength, flower and seed development and crop maturity. Similarly, N-fixation in legumes, crop quality and resistance against several plant diseases are the prominent features associated with phosphorus nutrition. The dynamics of soil $\mathrm{P}$ is characterized by biological (immobilization-mineralization) and physicochemical (sorption-desorption) processes. Extensive application of $\mathrm{P}$ fertilizer precipitated into the immobile pools with highly reactive $\mathrm{Ca}^{2+}$ in calcareous or normal soils and, $\mathrm{Fe}^{3+}$ and $\mathrm{Al}^{3+}$ in acidic soil (Mohammadi, 2012; Ezawa et al., 2002; Hao et al., 2002). The efficacy of $\mathrm{P}$ fertilizer is about $10-25 \%$ throughout the world and have very low level of bio-availability in soil, reaching the level of $1.0 \mathrm{mg} / \mathrm{kg}$ soil (Goldstein, 2000; Isherword, 1998).

Keeping in view the importance of maize in the agrobased economy and the deficiency of phosphorus in soil of Pakistan, the present research project was designed to study the effect of phosphorus sources and levels on spring maize crop.

\section{Materials and Methods}

The experiment was conducted at New Developmental Farm of the University of Agriculture Peshawar during the year 2014 in order to investigate phosphorus sources and their level on spring maize. The experiment was laid out in a randomized complete block design having three replications with a plot size of $5.40 \mathrm{~m} \times$ $6.7 \mathrm{~m}$ with plant to plant distance of $0.30 \mathrm{~m}$ and row to row distance of $0.70 \mathrm{~m}$. A basal dose of $150 \mathrm{~kg} / \mathrm{ha}$ nitrogen was applied at time of sowing. Hybrid maize was sown with recommended population of 60000 plants/ha. DAP, NP, TSP and SSP, and four P levels $(0,60,90$, and $120 \mathrm{~kg} / \mathrm{ha})$ were applied at the time of sowing.

Initial laboratory soil analysis. Laboratory soil analysis included soil pH (Mclean, 1982), EC (Richards, 1954), texture (Bouyoucos, 1936), lime (Richards, 1954), organic matter contents (Nelson and Sommer, 1982), mineral nitrogen (Bremner et al., 1996) and available P (Soltanpour., 1985).

Soil and agronomic analysis. Different agronomic data were recorded including plant height, number of cobs/plant, grain/ear, thousand grain weight $(\mathrm{g})$, biological yield $(\mathrm{kg} / \mathrm{ha})$, grain yield $(\mathrm{kg} / \mathrm{ha})$ and harvest index $(\%)$.

Statistical analysis. The data recorded was analyzed statistically using analysis of variance techniques appropriate for randomized complete block design. Means were compared using LSD test at 0.05 level of probability, when the F-value was significant.

\section{Results and Discussion}

Initial soil analysis. Clay loam to silt loam soils were observed in low permeability strata while sandy soils were observed in high permeability strata. Soil $\mathrm{pH}$ was dominantly alkaline in nature with no salinity indications. More than $75 \%$ samples were observed as moderate soil organic matter content. Most of the soil samples were calcareous with high lime content that could be attributed low rainfall and high temperature. Most of the areas were ranged from moderate to adequate level of $\mathrm{N}(0.18$ to $0.29 \%)$ while available $\mathrm{P}$ were ranged from 5.5 to $12.5 \mathrm{mg} / \mathrm{kg}$. Plant analyses included nitrogen concentration in plant leaf tissue, phosphorus and potassium concentration in plant leaves.

Plant height (cm). The data of plant height as influenced by different $P$ fertilizer sources and $P$ levels is depicted in Table 1. Interaction between P levels and sources was also found significant. Mean data for P levels exhibited that taller plants $(217.77 \mathrm{~cm})$ were produced when $\mathrm{P}$ was applied at the rate of $120 \mathrm{~kg} / \mathrm{P} / \mathrm{ha}$ which was statistically at par with $90 \mathrm{~kg} / \mathrm{ha}$, followed by $60 \mathrm{~kg} / \mathrm{P} / \mathrm{ha}(213.37 \mathrm{~cm})$, while short stature plants $(208.57 \mathrm{~cm})$ were recorded in control. When nitrophos was used as a source of $\mathrm{P}$ resulted in higher plant height $(220.25 \mathrm{~cm})$, however lower plant height $(205.20 \mathrm{~cm})$ was recorded when TSP was applied. Interaction between $120 \mathrm{~kg} / \mathrm{P} / \mathrm{ha}$ and NP resulted in significantly higher plant height. These findings are in agreement with those of Amanullah et al. (2010); Sahoo and Panda (2001) and Singaram and Kothandaraman (1994) who also reported that plant height in maize increased with increase in $\mathrm{P}$ level. This increase in plant height could be attributed to additional $\mathrm{N}$ in phosphatic fertilizers. 
Grains cob/g. Effect of P levels and various sources of $\mathrm{P}$ fertilizer on grains per ear is given in Table 2. Analysis of variance revealed that P levels as well as sources significantly affected grains/ear. However, interaction between P levels and sources were nonsignificant for grains/ear. More grains per ear (479) were counted for those plots where $\mathrm{P}$ was applied at the rate of $90 \mathrm{~kg} / \mathrm{ha}$, followed by $60 \mathrm{~kg} / \mathrm{P} / \mathrm{ha}(429)$, while minimum number of grains per ear was recorded in those plots where P was not applied. In case of P sources, higher number of grains/ear (464) were counted when SSP was used as a source of P, however lower grains per ear (405) were recorded for NP fertilizer. This indicated that $P$ level at the rate of $90 \mathrm{~kg} / \mathrm{ha}$ may be the optimum rate for obtaining maximum number of grains/ear, which ultimately had a direct effect on grain yield. Therefore, further increase in $\mathrm{P}$ level above $90 \mathrm{~kg} / \mathrm{ha}$ did not have linear effect on the number of grains/ear of maize, which is obvious from the plots with $\mathrm{P}$ application at the rate of $120 \mathrm{~kg} / \mathrm{ha}$ that had less number of grains/ear. Several other researchers also observed that phosphorous fertilizer applications significantly affected the grains per cob. (Masood et al., 2011; Sharma and Sharma, 1991; Arain et al., 1989).

Thousand grain weight (g). Table 3 shows the effect of various sources and various levels of phosphorus fertilizer on thousand grain weight of maize. Maximum thousand grain weight ( $251.67 \mathrm{gm}$ ) was recorded by the application of phosphorus at the rate of $90 \mathrm{~kg} / \mathrm{ha}$, whereas lowest value was recorded for control. In case of fertilizer sources, highest mean thousand grain weight (250.0 gm) was recorded by the application of SSP fertilizer, while lowest value (232.08 gm) was noted for TSP fertilizer. The present findings were supported by Amanullah et al. (2009), who observed maximum 1000 grain weight upon the application of higher $\mathrm{P}$ doses. Experimental results of the present study also agreed with the previous findings (Sahoo and Panda, 2001; Toor, 1990; Ahmad, 1989).

Biological yield (kg/ha). P sources and levels considerably affected biological yield, however, interaction between $P$ levels and sources was statistically nonsignificant (Table 4). Among the P levels, maximum biological yield $(9974 \mathrm{~kg})$ was produced at the rate of $90 \mathrm{~kg} / \mathrm{ha}$, followed by $120 \mathrm{~kg} / \mathrm{ha}(9111 \mathrm{~kg} / \mathrm{ha})$, which was statistically similar to $60 \mathrm{~kg} / \mathrm{P} / \mathrm{ha}(8821 \mathrm{~kg} / \mathrm{ha})$. While lower biological yield ( $7720 \mathrm{~kg} / \mathrm{ha}$ ) was obtained for control plots. This research is in line with the work
Table 1. Plant height of maize as affected by phosphorous sources and levels

\begin{tabular}{llllll}
\hline \hline \multirow{2}{*}{ P levels } & \multicolumn{4}{l}{ P Fertilizer sources } & \multirow{2}{*}{ Mean } \\
\cline { 2 - 5 } & DAP & NP & SSP & TSP & \\
\hline 0 & 204.40 & 212.60 & 212.93 & 204.33 & $208.57 \mathrm{c}$ \\
60 & 216.80 & 221.47 & 215.67 & 199.53 & $213.37 \mathrm{~b}$ \\
90 & 221.00 & 220.73 & 210.53 & 205.47 & $214.43 \mathrm{ab}$ \\
120 & 225.20 & 226.20 & 208.20 & 211.47 & $217.77 \mathrm{a}$ \\
Mean & $216.85 \mathrm{ab}$ & $220.25 \mathrm{a}$ & $211.83 \mathrm{ab}$ & $205.20 \mathrm{~b}$ & - \\
\hline \hline
\end{tabular}

LSD for P levels $=2$; LSD for P Fertilizers $=2$.

Table 2. Grains per ear as affected by phosphorous sources and levels

\begin{tabular}{llllll}
\hline \hline \multirow{2}{*}{ P levels } & \multicolumn{4}{c}{ P Fertilizer sources } & \multirow{2}{*}{ Mean } \\
\cline { 2 - 5 } & DAP & NP & SSP & TSP & \\
\hline 0 & 395 & 373 & 410 & 367 & $386 \mathrm{c}$ \\
60 & 474 & 393 & 443 & 406 & $429 \mathrm{~b}$ \\
90 & 491 & 458 & 515 & 452 & $479 \mathrm{a}$ \\
120 & 464 & 393 & 489 & 407 & $438 \mathrm{~b}$ \\
Mean & $456 \mathrm{ab}$ & $405 \mathrm{c}$ & $464 \mathrm{a}$ & $408 \mathrm{bc}$ & - \\
\hline \hline
\end{tabular}

LSD for P level $=49.05$; LSD for Fertilizer $=22.15$.

Table 3. Thousand grain weight as affected by phosphorous sources and levels

\begin{tabular}{llllll}
\hline \hline \multirow{2}{*}{ P levels } & \multicolumn{4}{c}{ P Fertilizer sources } & \multirow{2}{*}{ Mean } \\
\cline { 2 - 5 } & DAP & NP & SSP & TSP & \\
\hline 0 & 220 & 230 & 233 & 218 & $225 \mathrm{~b}$ \\
60 & 236 & 246 & 246 & 226 & $239 \mathrm{a}$ \\
90 & 251 & 251 & 256 & 246 & $251 \mathrm{a}$ \\
120 & 249 & 236 & 263 & 236 & $246 \mathrm{a}$ \\
Mean & $239 \mathrm{ab}$ & $241 \mathrm{ab}$ & $250 \mathrm{a}$ & $232 \mathrm{c}$ & - \\
\hline \hline
\end{tabular}

LSD for $\mathrm{P}$ level $=11.08512$; LSD for fertilizer $=12.84133$.

Table 4. Biological yield ( $\mathrm{kg} / \mathrm{ha})$ as affected by phosphorous sources and levels

\begin{tabular}{llllll}
\hline \hline \multirow{2}{*}{ P levels } & \multicolumn{4}{c}{ P Fertilizer sources } & \multirow{2}{*}{ Mean } \\
\cline { 2 - 5 } & DAP & NP & SSP & TSP & \\
\hline 0 & 7955 & 7297 & 8084 & 7542 & $7720 \mathrm{c}$ \\
60 & 9757 & 8053 & 9297 & 8177 & $8821 \mathrm{~b}$ \\
90 & 10862 & 8840 & 11004 & 9192 & $9974 \mathrm{a}$ \\
120 & 10057 & 9320 & 9182 & 7884 & $9111 \mathrm{~b}$ \\
Mean & $9658 \mathrm{a}$ & $8377 \mathrm{~b}$ & $9392 \mathrm{a}$ & $8199 \mathrm{~b}$ & - \\
\hline \hline
\end{tabular}

LSD for $\mathrm{P}$ level $=489.52$; LSD for fertilizer $=628.58$. 
of Bhopal and Singh (2004). They observed highest biological yield with highest $P$ application rate. Singaram and Kothandaraman (1994) also observed higher biomass yield by applying $\mathrm{P}$ in maize crop at $90 \mathrm{~kg} / \mathrm{ha}$. Higher biological yield $(9658 \mathrm{~kg} / \mathrm{ha})$ was recorded for those experimental units which received $\mathrm{P}$ in the form of DAP. Lower biological yield was obtained in those plots where TSP and NP (8199 and $8377 \mathrm{~kg} / \mathrm{ha}$, respectively) were applied as a source of $\mathrm{P}$.

Grain yield (kg). Table 5 presents data on grain yield as affected by P levels and sources. Statistical analysis of the data showed significance among P levels and sources, as well as the interaction between them. Mean maximum grain yield $(2965 \mathrm{~kg} / \mathrm{ha})$ was recorded where $\mathrm{P}$ was applied at $90 \mathrm{~kg} / \mathrm{ha}$, followed by $60 \mathrm{~kg} / \mathrm{P} / \mathrm{ha}$ (2599 $\mathrm{kg} / \mathrm{ha})$, while minimum grain yield $(2155 \mathrm{~kg} / \mathrm{ha})$ was obtained in control plots. In case of P sources, DAP and SSP produced significantly higher grain yield (2838 and $2815 \mathrm{~kg} / \mathrm{ha}$, respectively) compared to TSP and NP (2371 and $2349 \mathrm{~kg} / \mathrm{ha}$, respectively). Interaction of 90 $\mathrm{kg} / \mathrm{P} / \mathrm{ha}$ and SSP produced significantly higher grain yield. This work is in line with the previous work of Arain et al. (1989), who reported that increasing $P$ application increase yield of maize. Hussain and Haq (2006) also reported similar results that grain yield was increased with the application of phosphorus at $90 \mathrm{~kg} / \mathrm{P} / \mathrm{ha}$ compared to control. Experimental results are also in agreement with those of Duggul (1990) and Hanif (1990), who observed higher grain yield of maize crop by applying phosphorus fertilizers.

Harvest index (\%). Data concerned with harvest index are reported in Table 6. Phosphorus sources and their levels had no significant effect on harvest index of spring maize, while interaction was also found nonsignificant for harvest index.

Soil pH. Data related with soil $\mathrm{pH}$ are reported in Table 7. Phosphorus sources and their levels had significant affect on soil $\mathrm{pH}$, while interaction was found non-significant for soil $\mathrm{pH}$. Regarding phosphorus levels maximum soil $\mathrm{pH}$ (7.51) was recorded for control, while $60,90,120 \mathrm{~kg} / \mathrm{P} / \mathrm{ha}$ produced statistically same soil $\mathrm{pH}$. In case $\mathrm{P}$ sources maximum soil $\mathrm{pH}$ (7.53) was recorded for DAP and lower $\mathrm{pH}$ was recorded for SSP (7.47). Amanullah et al. (2010) and Yash et al. (1992) also reported that high soil $\mathrm{pH}$ decreased by increasing $\mathrm{P}$ level. Decrease a little bit in soil $\mathrm{pH}$ with SSP and TSP could be attributed to releasing of more $\mathrm{H}^{+}$ion in the soil. When SSP and TSP mix with the soil solution in the form of $\mathrm{H}_{2} \mathrm{PO}_{4}{ }_{4}^{-}$, it could acidify the soil $\mathrm{pH}$.
Table 5. Grain yield as affected by phosphorous sources and levels

\begin{tabular}{llllll}
\hline \hline \multirow{2}{*}{ P levels } & \multicolumn{4}{c}{ P Fertilizer sources } & \multirow{2}{*}{ Mean } \\
\cline { 2 - 5 } & DAP & NP & SSP & TSP & \\
\hline 0 & 2408 & 1802 & 2337 & 2073 & $2155 \mathrm{c}$ \\
60 & 2832 & 2191 & 3040 & 2333 & $2599 \mathrm{~b}$ \\
90 & 3076 & 2572 & 3508 & 2705 & $2965 \mathrm{a}$ \\
120 & 3038 & 2831 & 2375 & 2371 & $2654 \mathrm{~b}$ \\
Mean & $2838 \mathrm{a}$ & $2349 \mathrm{~b}$ & $2815 \mathrm{a}$ & $2371 \mathrm{~b}$ & - \\
\hline \hline
\end{tabular}

LSD for $\mathrm{P}$ level $=246.85$; LSD for fertilizer $=398.25$.

Table 6. Harvest index as affected by phosphorous sources and levels

\begin{tabular}{llllll}
\hline \hline P levels & \multicolumn{4}{c}{ P Fertilizer sources } & \multirow{2}{*}{ Mean } \\
\cline { 2 - 5 } & DAP & NP & SSP & TSP & \\
\hline 0 & 30.28 & 24.74 & 28.90 & 27.34 & 27.82 \\
60 & 28.79 & 27.20 & 32.66 & 28.57 & 29.31 \\
90 & 28.33 & 29.11 & 31.85 & 29.44 & 29.68 \\
120 & 30.14 & 30.49 & 25.60 & 30.07 & 29.08 \\
Mean & 29.39 & 27.89 & 29.75 & 28.86 & - \\
\hline \hline
\end{tabular}

Table 7. Soil $\mathrm{pH}$ as affected by phosphorus levels and sources

\begin{tabular}{llllll}
\hline \hline P levels & \multicolumn{4}{c}{ P Fertilizer sources } & Mean \\
\cline { 2 - 5 } & DAP & NP & SSP & TSP & \\
\hline 0 & 7.51 & 7.51 & 7.50 & 7.51 & $7.51 \mathrm{a}$ \\
60 & 7.52 & 7.50 & 7.48 & 7.49 & $7.50 \mathrm{~b}$ \\
90 & 7.53 & 7.49 & 7.46 & 7.48 & $7.49 \mathrm{~b}$ \\
120 & 7.55 & 7.49 & 7.44 & 7.47 & $7.49 \mathrm{~b}$ \\
Mean & $7.53 \mathrm{c}$ & $7.50 \mathrm{~b}$ & $7.47 \mathrm{c}$ & $7.49 \mathrm{~b}$ & - \\
\hline \hline
\end{tabular}

LSD for P level $=0.009$; LSD for fertilizer $=0.012$.

Electrical conductivity $(\mathbf{d S} / \mathbf{m})$. Data consisted with soil EC are reported in Table 8. Phosphorus sources and their levels had significant effect on soil EC, while interaction was found non-significant for soil EC. Regarding phosphorus levels maximum soil EC (0.20) was recorded for control but it was non-significant.

Mineral nitrogen in soil. Analysis of the data exhibited that $\mathrm{P}$ levels had no significant affect on soil mineral nitrogen content however, there was significant difference recoded among the $\mathrm{P}$ sources. Maximum soil mineral nitrogen (19.52) was recorded when NP was applied but it was statistically not different from DAP applied treatment (14.63). Lower soil mineral nitrogen content (10.15) was recorded for SSP treatments. No 
interaction occurred between P levels and sources for soil mineral nitrogen content. Phosphatic fertilizer also contain some amount of nitrogen which could affect soil mineral nitrogen during the application. Application of inorganic fertilizer may increase or balance the soil mineral nitrogen contents as described by Tadesse et al. (2013).

Phosphorous concentration in leaves $(\mathrm{mg} / \mathrm{kg})$. Data regarding the $\mathrm{P}$ content of plants as influenced by $\mathrm{P}$ levels and fertilizer sources is shown in Table 9. There was considerable effect of $P$ levels and sources on $P$ concentrations of plant leaves. In case of $\mathrm{P}$ levels, higher $\mathrm{P}$ concentration was determined for those plots that received $\mathrm{P}$ at the rate of 120 and $90 \mathrm{~kg} / \mathrm{ha}$. However, lower $P$ concentration $(0.15 \mathrm{mg} / \mathrm{kg})$ was recorded in case of control plots. Among the sources, higher P concentration was recorded for SSP $(0.24 \mathrm{mg} / \mathrm{kg})$, followed by NP and TSP $(0.19 \mathrm{mg} / \mathrm{kg})$, while low P concentration $(0.15 \mathrm{mg} / \mathrm{kg})$ was determined for DAP. Maximum $\mathrm{P}$ concentrations in leaves were determined with 90 and $120 \mathrm{~kg} / \mathrm{P} / \mathrm{ha}$ application rates. Similar results were recorded in case of egg plant by Lopez-Cantarero et al. (1992). The reason of no increase in P concentration could be due to less uptake of crop plants and also uneven distribution of roots which could have not easy access to the applied P. It may also be due to immobility of $\mathrm{P}$ in soil which does not move far in the soil to reach the plant roots.

Potassium concentration in plant leaves $(\mathrm{mg} / \mathrm{kg})$. Data related to K concentration in plant is shown in Table 10. Phosphorus sources and their levels had significantly affected $\mathrm{K}$ concentration in plant, while interaction was found non-significant. Regarding phosphorus levels, maximum $\mathrm{K}$ concentration in plant (1.70) was recorded in case of $120 \mathrm{~kg} / \mathrm{P} / \mathrm{ha}$. However, it was not statistically different from $\mathrm{K}$ concentration in plant (1.68). In case of $P$ sources, maximum $K$ concentration in plant (1.71) was recorded for TSP, followed by NP (1.59). While DAP applied plants have lowest (1.54) $\mathrm{K}$ concentration. These findings indicated that $120 \mathrm{~kg} / \mathrm{P} / \mathrm{ha}$ was the optimum concentration, and TSP was the suitable source for obtaining maximum $\mathrm{K}$ concentration in plant leaves. Further increase in $\mathrm{P}$ level above $120 \mathrm{~kg} / \mathrm{ha}$ did not show a linear effect on the K concentration of the leaf. These findings are in accordance with those of Masood et al. (2011).

Nitrogen concentration in plant leaves. Data related to $\mathrm{N}$ concentration data in plant is shown in Table 11. Phosphorus sources and their levels had significantly
Table 8. Electrical conductivity as affected by phosphorous sources and levels

\begin{tabular}{llllll}
\hline \hline \multirow{2}{*}{ P levels } & \multicolumn{4}{c}{ P Fertilizer sources } & \multirow{2}{*}{ Mean } \\
\cline { 2 - 5 } & DAP & NP & SSP & TSP & \\
\hline 0 & 0.19 & 0.20 & 0.20 & 0.20 & $0.20 \mathrm{a}$ \\
60 & 0.20 & 0.20 & 0.19 & 0.19 & $0.20 \mathrm{a}$ \\
90 & 0.20 & 0.19 & 0.18 & 0.19 & $0.19 \mathrm{~b}$ \\
120 & 0.21 & 0.18 & 0.18 & 0.18 & $0.19 \mathrm{~b}$ \\
Mean & $0.20 \mathrm{a}$ & $0.19 \mathrm{~b}$ & $0.19 \mathrm{~b}$ & $0.19 \mathrm{~b}$ & - \\
\hline \hline
\end{tabular}

LSD for $\mathrm{P}$ level $=0.006 ; \mathrm{LSD}$ for fertilizer $=0.007$.

Table 9. Plant phosphorous concentration as affected by phosphorous sources and level $(\mathrm{mg} / \mathrm{kg})$

\begin{tabular}{|c|c|c|c|c|c|}
\hline \multirow[t]{2}{*}{ P levels } & \multicolumn{4}{|c|}{ P Fertilizer sources } & \multirow[t]{2}{*}{ Mean } \\
\hline & DAP & NP & SSP & TSP & \\
\hline 0 & 0.14 & 0.15 & 0.15 & 0.17 & $0.15 \mathrm{c}$ \\
\hline 60 & 0.15 & 0.19 & 0.23 & 0.18 & $0.19 \mathrm{~b}$ \\
\hline 90 & 0.18 & 0.21 & 0.29 & 0.20 & $0.22 \mathrm{a}$ \\
\hline 120 & 0.17 & 0.22 & 0.30 & 0.21 & $0.23 \mathrm{a}$ \\
\hline Mean & $0.16 \mathrm{c}$ & $0.19 b$ & $0.24 \mathrm{a}$ & $0.19 b$ & - \\
\hline
\end{tabular}

LSD for $\mathrm{P}$ level $=0.019489$; LSD for fertilizer $=0.021881$.

Table 10. Plant potassium concentration as affected by phosphorous sources and levels

\begin{tabular}{|c|c|c|c|c|c|}
\hline \multirow[t]{2}{*}{ P levels } & \multicolumn{4}{|c|}{ P Fertilizer sources } & \multirow[t]{2}{*}{ Mean } \\
\hline & DAP & NP & SSP & TSP & \\
\hline 0 & 1.39 & 1.56 & 1.59 & 1.61 & 1.54 \\
\hline 60 & 1.47 & 1.69 & 1.64 & 1.71 & 1.63 \\
\hline 90 & 1.75 & 1.61 & 1.73 & 1.62 & 1.68 \\
\hline 120 & 1.55 & 1.48 & 1.89 & 1.88 & 1.70 \\
\hline Mean & $1.54 \mathrm{c}$ & $1.59 \mathrm{~b}$ & $1.71 \mathrm{a}$ & $1.71 \mathrm{a}$ & - \\
\hline
\end{tabular}

LSD for P level $=0.10489$; LSD for fertilizer $=0.110995$.

Table 11. Plant nitrogen concentration as affected by phosphorous sources and levels (\%)

\begin{tabular}{|c|c|c|c|c|c|}
\hline \multirow[t]{2}{*}{ P levels } & \multicolumn{4}{|c|}{ P Fertilizer sources } & \multirow[t]{2}{*}{ Mean } \\
\hline & DAP & NP & SSP & TSP & \\
\hline 0 & 1.19 & 1.24 & 1.34 & 1.29 & 1.27 \\
\hline 60 & 1.31 & 1.45 & 1.51 & 1.28 & 1.39 \\
\hline 90 & 1.47 & 1.52 & 1.53 & 1.30 & 1.46 \\
\hline 120 & 1.49 & 1.45 & 1.63 & 1.36 & 1.48 \\
\hline Mean & $1.37 \mathrm{c}$ & $1.42 \mathrm{~b}$ & $1.50 \mathrm{a}$ & $1.31 \mathrm{~d}$ & - \\
\hline
\end{tabular}

LSD for P level $=0.08057$; LSD for fertilizer $=0.078962$. Means in the same row with different letters in Table 1-11 represent the significant differences between variables. 
affected $\mathrm{N}$ concentration in plant, while interaction was found non-significant. Regarding P levels, maximum $\mathrm{N}$ concentration in plant (1.48) was recorded for 120 $\mathrm{kg} / \mathrm{P} / \mathrm{ha}$; however it was not statistically different from $\mathrm{N}$ concentration in plant (1.46), when $60 \mathrm{~kg} / \mathrm{P} / \mathrm{ha}$ was applied. Lowest plant $\mathrm{N}$ concentration was found for control (1.27). In case of $P$ sources, maximum $\mathrm{N}$ concentration in plant (1.50) was recorded for NP followed by SSP (1.42), while TSP applied plot plant have lowest $\mathrm{N}$ concentration. The analysis showed that $120 \mathrm{~kg} / \mathrm{ha}$ was optimum level and SSP was suitable source for obtaining maximum $\mathrm{N}$ concentration in plant leaf. These findings are in accordance with those of Amin and Hussain (2011).

\section{Conclusion}

Among all the phosphorus sources, application of SSP provided better results in terms of yield and yield components of maize crop. Plant P concentration was also increased with the application of SSP source. The highest yield and yield components were recorded when $\mathrm{SSP}$ was used at $90 \mathrm{~kg} / \mathrm{P} / \mathrm{ha}$.

Conflict of Interest. The authors declare no conflict of interest.

\section{References}

Ahmad, I. 1989. The Effect of Phosphorus Application in Different Proportions with Nitrogen on the Growth and Yield of Maize. M.Sc. (Hons.) Agri. Thesis, Department of Agronomy, University of Agriculture, Faisalabad, Pakistan.

Ahmad, N., Saleem, M.T., Twyford, I.T. 1992. Phosphorus research in Pakistan-A review. In: Proceeding Symposium, On the Role of Phosphorus in Crop Production, pp. 59-92, NFDC, Islamabad, Pakistan.

Amanullah, K., Zakirullah. M., Tariq, M., Nawab, K., Khan, A.Z., Farhatullah., Shah, Z., Jan, A., Khalil, S.K., Jan, M.T., Sajid, M., Hussain, Z., Rahman, H.U. 2010. Levels and time of phosphorus application influence growth, dry matter partitioning and harvest index in maize. Pakistan Journal of Botany, 42: 4051-4061.

Amanullah, K., Khalil, R.A., Khalil, S.K. 2009. Effects of plant density and $\mathrm{N}$ on phonology and yield of maize. Journal of Plant Nutrition, 32: 245-259.

Amin, M., Hussain. 2011. Effect of different nitrogen sources on growth, yield and quality of fodder maize (Zea mays L.). Journal of Saudi Society of Agricultural Sciences, 10: 17-23.

Arain, A.S., Aslam, S.M., Tunio, A.K.G. 1989. Performance of maize hybrids under varying NP fertilizer environments. Sarhad Journal of Agriculture, 5: 623-626.

Bakht, J., Ahmad, S., Triq, M., Akber, H., Shafi, M. 2006. Response of maize to planting methods and fertilizer nitrogen. Journal of Biological Science, 1: 8-14.

Barber, S.A. 1995. Soil Nutrient Bioavailability: A Mechanistic Approach, 384 pp., 2nd edition, John Wiley \& Sons, USA.

Bhopal, S., Singh, B. 2004. Response of phosphorus on yield of maize and wheat in sequence under rain-fed conditions. Indian Agriculture and Research Journal, 23: 184-186.

Bouyoucos, G.J. 1936. Directions for making mechanical analysis of soils by the hydrometer method. Soil Science Society of American Journal, 43: 225-228.

Bremner, J.M., Sparks, A.L., Helmke, R.H., Loeppert, P.N., Sotanpour, M.A., Tabatabai, C.T., Johnston S.M.E. 1996. Nitrogen-total. Soil Science Society of American Journal, 3: 1085-1121.

Chaudhary, A.R. 1983. Maize in Pakistan. Punjab Agriculture Research Coordination Board, University of Agriculture, Faisalabad, Pakistan.

Chen, M., Rao, R.S.P., Zhang, Y., Zhong, C., Thelen, J.J. 2016. Metabolite variation in hybrid corn grain from a large-scale multisite study. The Crop Journal, 4: 177-187.

Duggul, M.M. 1990. Response of some New Maize Genotypes to NPK Application. M.Sc. (Hons.) Thesis, Department of Agronomy, University of Agriculture, Faisalabad, Pakistan.

Ezawa, T., Smith, S.E., Smith, F.A. 2002. P metabolism and transport in AM fungi. Plant Soil, 244: 221-230.

Goldstein, A.H. 2000. Bioprocessing of rock phosphate ore: essential technical considerations for the development of a successful commercial technology. Proceedings of $4^{\text {th }}$ International Fertilizer Association Technology Conference, IFA, Paris, 220 pp.

GOP, 2010-2011. Agriculture Statistics of Pakistan, pp. 92, Government of Pakistan, Statistics Division, Pakistan Bureau of Statistics, Islamabad, Pakistan.

Hanif, M. 1990. Growth and Yield of Maize Genotypes as Influenced by NPK Application. M.Sc. (Hons.) Thesis, University of Agriculture, Faisalabad, Pakistan. 
Hao, X., Cho, C.M., Racz, G.J., Chang, C. 2002. Chemical retardation of phosphate diffusion in an acid soil as affected by liming. Nutrition Cycle in Agroecosystem, 64: 213-224.

Hussain, M.Z., Haq, I.U. 2006. Phosphorus sorption capacities of NWFP soils. In: Proceedings of Symposium on Integrated Plant Nutrient Management, held at Islamabad, pp. 284-296, Islamabad, Pakistan.

Isherword, K.F. 1998. Fertilizer use and environment. In: Proceedings Symposium on Plant Nutrition Management for Sustainable Agricultural Growth. N. Ahmed and A. Hamid (eds.), pp. 57-76, NFDC, Islamabad, Pakistan.

Lee, J., Nam, D.S., Kong, C. 2016. Variability in nutrient composition of cereal grains from different origins. Springer Plus, 5: 419.

Lopez-Cantarero, I., Sanchez, A., delRio, A., Valenzuela, J.L., Romero, L. 1992. What constitutes a good iron indicator with brackish water and gypsum. Journal of Plant Nutrition, 15: 1567-1578.

Masood, T., Rozina. G., Fazal, M., Fazal. J., Zahid. H., Nadia, N., Hamayoon, K., Nasiruddin, Hayatullah, K. 2011. Effect of different phosphorus levels on the yield and yield components of maize. Sarhad Journal of Agriculture, 27: 167-170.

McLean, E.O. 1982. Soil $\mathrm{pH}$ and lime requirement. In: Methods of Soil Analysis (2). E. L. Page, A. L. R. H. Miller and D. R. Keeney (eds.), Chemical and Microbiological Properties No. 9 in the series, Agronomy, pp. 199-224, $2^{\text {nd }}$ edition, American Society of Agronomy, Soil Science Society of America, Madison, USA.

Mohammadi, K. 2012. Phosphorus solubilizing bacteria: occurrence, mechanisms and their role in crop production. Resource Environment, 2: 80-85.

Nelson, D.W., Sommer, L.E. 1982. Total carbon and organic matter. In: Methods of Soil Analysis. Part 2, R. H. Miller, D. R. Keeney (eds.), $2^{\text {nd }}$ edition, pp. 574-577, American Society of Agronomy, Soil Science Society of America, Madison, USA.

Rashid, A., Din, J., Bashir, M. 1999. Phosphorus deficiency diagnosis and fertilization in mung bean grown in rainfed calcareous soils of Pakistan. Communications in Soil Science and Plant Analysis, 30: 2045-2056.

Richards, L.A. 1954. Diagnosis and Improvement of
Saline and Alkali Soils. USDA Agriculture Handbook. 60, Washington. DC, USA.

Sahoo, S.C., Panda, M. 2001. Effect of phosphorus and tasseling on yield of baby-corn. Indian Journal of Agriculture Sciences, 71: 21-22.

Sharma, J.P., Sharma, U.C. 1991. Effect of nitrogen and phosphorus on the yield and severity of blight disease in maize Nagaland. Indian Phytopathology, 44: 383-385.

Singaram, P., Kothandaraman, G.V. 1994. Studies on residual, direct and cumulative effect of phosphorus sources on the availability, content and uptake of phosphorus and yield of maize. Madras Agriculture Journal, 81: 425-429.

Soltanpour, P.N. 1985. Use of AB-DTPA soil test to evaluate elemental availability and toxicity. Communication in Soil Science Plant Analysis, 16: 323338.

Tadesse, T., Dechassa, N., Bayu, W., Gebeyehu, S. 2013. Effect of farmyard manure and inorganic fertilizer application on soil physico-chemical properties and nutrient balance in rain-fed lowland ecosystem. American Journal of Plant Sciences, 4: 309-316.

Toor, S.A. 1990. Effect of NPK Application on the Growth and Yield of New Maize Genotypes Planted in Two Geometrical Pattern. M.Sc. (Hons.) Agri. Thesis, Department of Argonomy, University of Agriculture, Faisalabad, Pakistan.

Watson, S.A. 2003. Description, development, structure and composition of the corn kernel. Corn: Chemistry and Technology, 2: 69-106.

Yash, S., Rakish, W., Sing, K. 1992. Phosphorus availability under different soil $\mathrm{pH}$. Indian Agricultural Journal, 23: 124-128.

Zia, M.S., Gill, M.A., Aslam, M., Hussain, M.F. 1991. Fertilizer use efficiency in Pakistan. Progressive Farming, 11: 8-35.

Zhu, J., Kaeppler, S.M., Lynch, J.P. 2005a. Mapping of QTLs for lateral root branching and length in maize (Zea mays L.) under differential phosphorus supply. Theoretical and Applied Genetics, 111: 688-695.

Zhu, J., Kaeppler, S.M., Lynch, J.P. 2005b. Mapping of QTL controlling root hair length in maize (Zea mays L.) under phosphorus deficiency. Plant and Soil, 270: 299-310. 